\title{
PANEL GRANGER CAUSALITY ANALYSIS OF RELATIONSHIPS BETWEEN TOURISM AND ECONOMIC GROWTH IN THE TOP EIGHT TOURIST DESTINATIONS
}

The tourism has economic, social and political effects and contributes to the economic development of many countries. Interaction levels of national economies increase with tourism through globalization. This study aims to test the causality relationship between the components of the tourism and economic growth. The causality relationship between the components of the tourism and economic growth by using panel causality analysis method. The findings indicate a bi-directional causality relationship between growth and tourism expenditures and tourism revenues. Tourism expenditures, tourism receipts and number of international arrivals are parameters of the tourism. Real gross domestic product is used as a growth indicator. The top eight tourist destinations are analyzed; Spain, Italy, Russia, Turkey, France, China, USA, UK. In this context; A panel dataset was created for the top eight tourism countries over the period 1995-2017. The arrivals of tourists, expenditure levels of tourists and tourism receipts are important indicators for the national economies. The positive effects of these indicators on the balance of payments, being a source of foreign exchange, employment creation, triggering investment in infrastructure and superstructure and creating a revitalizing effect in other sectors, have an important place in the region and country economy with their socio-cultural reflections.

Keywords: Economic growth, tourism expenditures, tourism receipts, number of international arrivals, panel granger casuality

* Ö. B. Soylu, PhD, Assistant Professor, Faculty of Economics and Administrative Sciences, Kocaeli University, Turkey (e-mail: ozgurbayram.soylu@kocaeli.edu.tr). The paper was received on 3.12.2018. It was accepted for publication on 20.05.2020. 


\section{Introduction}

Tourism activities and components are becoming increasingly important in the globalizing world economy. Tourism is an economic activity that is the fastest developing world in the world with the increase in travel expenses and transportation opportunities and is the pioneer of economic, social, political and psychological improvements for developed and developing country economies (Shahzad et.al, 2017). The United Nations World Tourism Organization (UNWTO) predicts that the international tourist volume will increase and reach 1.8 billion in 2030, which will increase the competition in tourism. It is an undeniable fact that tourism activities contribute positively to macro and micro magnitudes of the national economies especially economic growth and employment. More specifically, Tourism contributes to increasing the level of economic activity in a wide macroeconomic framework, from employment to infrastructure, from tax revenues to technological development, by increasing the competitiveness of firms. Tourism revenues have an important position especially for the economies in need of foreign currency in terms of financing the current account deficit. The growth of tourism has cause to direct and indirect growth in household incomes and public incomes through developing multiplier effects, improving the balance of payments and implementing government policies to support tourism (Belloumi, 2010). Also, tourism promotes to cultural exchanges and practices between countries of origin and countries of origin, thereby increasing social capital. Finally, due to the attempts in nature tourism, the tourism can also be an forceful catalayst for the conservation of the nature and wild life (Shahzad et.al, 2017). The poised and appropriate growth of the tourism economy concerning other economic activity sectors, particularly agriculture and industry, provides the provision of food and capital equipment for the production of tourism products (Dritsakis, 2012). Tourism operation is considered as a dynamic of economic growth due to all these effects.

Although tourism expenditures vary according to the level of development between countries, it also leads to a capital flow from developed countries to developing countries or less developed countries and from developing countries to less developed countries. The tourism remains among the alternative dynamics of economic growth in developing economies. The tourism has become a major source of employment as it is mostly labour density. Moreover, tourism has become an substantial sector in economic progress and growth due to its contribution to the balance of employment, production and payments.

The tourism has a similar importance to the selected economies. The important of inflow of receipts in economies attract attention in addition to being an international tourism centre. A tourism-led growth hypothesis suggests the existence of several parameters that tourism will be the key consideration of long- 
term economic growth as an export based growth hypothesis (Balaguer and Cantavella-Jorda, 2002). Also, international tourism promotes to income growth in at least two additional process. As Bhagwati and Srinivasan (1979) argue increasing productivity through competition between domestic firms and those corresponding to other international tourist arrivals contributes to revenue growth. Secondly, Helpman and Krugman (1985) point out that the most important step to increase income in local economies is the existence of economies of scale and increasing the utilization opportunities.

Balaguer and Cantavella-Jorda (2002) emphasize that spending per tourist is predominantly concentrated in non-commercial goods and services. Consequently, positive and negative effects may occur on economic growth. It should not be overlooked that the prices of non-commercial goods and services cannot be exported depending on the determination in the local market. Therefore, the fact that tourists consume non-commercial goods and services will also have an impact on the relative price of these goods.

The relationship between economic growth and tourism depends on many factors considering the structure of the tourism. The impact of tourism activities on economic growth during periods of economic expansion and stagnation has a changing trend of interaction. This interaction draws attention not only in periods of expansion and stagnation but also in fluctuations in tourism activities. The effects of the fluctuation in tourism activities on economic growth can occur asymmetrically (Shahzad et al., 2017). Çetintaş and Bektaş (2008) summarize why the developments in the tourism are the determinants of economic growth in four items:

- Tourism revenues are included in the national income and have a multiplier effect on the national economy, and this multiplier effect has a positive effect on the economy and supports many sectors.

- Tourism employs educated and skilled labour force and employs people who do not have enough education.

- Tourism allows the interaction of different cultures

- International tourism provides export-focused growth in at least two aspects.

The relationship between tourism spending and economic growth has attracted attention in the literature as a subject worth exploring in different period intervals for various country groups in recent years. Knowledge of the causal relationship between tourism expenditures and growth is significant for policy, as tourism policies raise great concerns for these economies. Regardless of the development level of the countries, tourism expenditures and receipts have an important share in the economic growth of the countries. Also, the effect of tourism expenditures and receipts on employment is an undeniable fact. This study aims to test the causality relationship between the components of the tourism, which are tourism expen- 
ditures, tourism receipts and the number of international arrivals, and economic growth at the top eight tourist destinations. What makes this study different from other studies is that it is a study of the country's group, but it is a study that takes into account the horizontal cross-sectional dependence.

Also this paper aims to research tourism and growth relation in the eight most popular destinations (Spain, Italy, Russia, Turkey, France, China, United States and The United Kingdom) using Pedroni Cointegration and Panel Granger Test. The number of arrivals, international tourism receipts and international tourism (travel) expenditures is considered as a tourism indicator.

The rest of the paper is organized as follows: Section 2 describes literature review. Section 3 provides the data, methodology and evidences. The last part presents a discussion and conclusion.

\section{Literature Review}

Tourism is a very important chance especially for underdeveloped and developing countries. The studies conducted for these countries promotes the thesis that tourism causes to economic growth. The analysis shows that there is a long-term stable relationship between economic growth and tourism expansion (Sequeira and Nunes, 2008; Chen and Chiou-Wei, 2009; Dritsakis, 2004; Shahbaz et.al, 2017; Balaguer and Cantavella-Jordan, 2002; Dritsakis, 2012). The tourism and economic growth relation as an empirical perspective is pioneered by Ghali (1976). Balaguer and Cantavella- Jorda (2002) pioneered the study of the validity of the "Tourism and Long-run Economic Growth "(TLG) hypothesis. It shows that the relationship between tourism development and growth is fundamentally favourable for whole economies and although there are huge discrepancy in different amounts of tourism and between per capita income in each groups (Shahzad et.al.,2017).

Tourism-Led Growth Hypothesis is derived from the export-based growth hypothesis which suggests that economic growth depends on developments in export volume as well as the amount of labour and capital (Brida et. al (2016)). Tourism-Led Growth Hypothesis mainly refers to a unidirectional causality relationship from tourism activities to economic growth. At the same time, tourism activities promote economic growth by increasing employment as well as increasing income. TLGH states that economic growth is supported due to the upward developments in the exchange rate rather than human capital and technological development (da Costa Ribeiro \& Wang (2020)). 
Dritsakis (2004), Lee and Chien (2008) analyze to common mobility and causal relation between real gross domestic product, tourism growth parametres, and real exchange rate, using unit root tests and cointegration tests. The results show that there is is bi-directional relation between tourism and economic growth (also Pérez-Rodríguez et.al, 2015; Shahzad et.all 2017; Tuğcu 2014)

Belloumi (2010) analyze the contribution of tourism in Tunisia's growth and the relationship between revenues, gross domestic product, effective exchange rates between 1970 and 2007. It has been found that there is a relation between revenues, growth and tourism has a positive impact on gross domestic product indirectly.

Chou (2013) states that empirical evidence is four main policy implications. The domestic tourism expenditures leads to growth, it means that travel expenditures promotes growth. Therefore, policies to be implemented in order not to be affected by negative tourism shocks will suppress economic expansion. This condition was likely to occur under conditions of growth, mainly based on domestic tourism expenditures. Second, the causality from growth to tourism expenditures shows that protection policies have low or no impact on growth. For the relationship between tourism expenditures and growth to have an impact on economic activity, the reduction of the share of expenditures allocated to sustainable tourism and tourism are important criteria. Fourth, the neutrality between tourism expenditures and growth persists, it will enable policy wonks to improve policies that are not linked to growth.

The principal economic utility by tourism activities involve foreign exchange earnings, employment and revenue (Archer, 1995; Belisle and Hoy, 1980; Davis et.al., 1988; Durbarry, 2002). Durbarry (2002) evaluated the causality relation between trade in goods and growth based on these results tested the effect of tourism using a production function. Tourism-driven growth tends to emerge when it shows an incentive effect in the type of sprawl and other externalities throughout the tourism (Marin, 1992). Oh (2005), Payne and Mervar (2010), Lee (2012 examined the relationship between tourism and development in Korea within the framework of the tourism-based growth hypothesis, economically driven tourism growth hypothesis and bidirectional causality. It is important to identify the causal relationship between tourism and economic growth to diversify tourism marketing strategies and make effective policy decisions. Therefore, this study aims to help to analyze the causality problem between tourism and economic growth (Oh, 2005). Pablo-Romero and Molina (2013) provide a depictive review of experimental results that analyzes the relations between tourism and growth. In light of this literature, in the following section, the causal relation between growth and tourism is investigated for the selected eight most popular destinations.

The studies and findings examining the interaction of tourism activities with economic growth and other macroeconomic indicators are summarized in Table 1. 
Table 1.

\section{LITERATURE SURVEY}

\begin{tabular}{|c|c|c|c|c|}
\hline Authors & \begin{tabular}{|l|} 
Method \\
\end{tabular} & Counrty & Period & Findings \\
\hline $\begin{array}{l}\text { Balaguer \& } \\
\text { Cantavella- } \\
\text { Jorda (2002) }\end{array}$ & \begin{tabular}{|l|} 
Granger \\
causality tests
\end{tabular} & Spain & $\begin{array}{l}1975- \\
1997\end{array}$ & $\begin{array}{l}\text { Economic growth and } \\
\text { tourism expansion have } \\
\text { long-run relation. }\end{array}$ \\
\hline $\begin{array}{l}\text { Lee \& Chang } \\
(2008)\end{array}$ & $\begin{array}{l}\text { Panel } \\
\text { causality tests }\end{array}$ & $\begin{array}{l}\text { OECD and } \\
\text { nonOECD } \\
\text { countries }\end{array}$ & $\begin{array}{l}1990- \\
2002\end{array}$ & $\begin{array}{l}\text { The panel causality test } \\
\text { indicate unidirectional } \\
\text { causality tourism } \\
\text { development to economic } \\
\text { growth in OECD } \\
\text { countries, bidirectional } \\
\text { causality in nonOECD } \\
\text { countries, but only weak } \\
\text { causality in Asia in the } \\
\text { long run. }\end{array}$ \\
\hline $\begin{array}{l}\text { Jimenez and } \\
\text { Pulina (2010) }\end{array}$ & VECM & Italy and Spain & $\begin{array}{l}1954- \\
2000\end{array}$ & $\begin{array}{l}\text { Inbound tourism } \\
\text { is effective in both } \\
\text { economies. }\end{array}$ \\
\hline $\begin{array}{l}\text { Nissan et.al. } \\
\text { (2011) }\end{array}$ & $\begin{array}{l}\text { Ordinary } \\
\text { least squares }\end{array}$ & $\begin{array}{l}\text { Denmark, } \\
\text { Finland, } \\
\text { France, } \\
\text { Germany, Italy, } \\
\text { Japan, The } \\
\text { Netherlands, } \\
\text { Spain, Sweden, } \\
\text { the } \\
\text { UK and the } \\
\text { USA }\end{array}$ & $\begin{array}{l}2000- \\
2005\end{array}$ & $\begin{array}{l}\text { Tourism has a } \\
\text { positive impact on } \\
\text { economic growth and } \\
\text { entrepreneurship; prices } \\
\text { and income also have } \\
\text { significant effects on } \\
\text { tourism. }\end{array}$ \\
\hline $\begin{array}{l}\text { Mahmoudinia } \\
\text { et. al (2011) }\end{array}$ & $\begin{array}{l}\text { Panel } \\
\text { cointegration }\end{array}$ & 17 MENA & $\begin{array}{l}1995- \\
2007\end{array}$ & $\begin{array}{l}\text { Tourism promotes } \\
\text { economic growth in } \\
\text { MENA in the } \\
\text { short-run and long run. }\end{array}$ \\
\hline $\begin{array}{l}\text { Husein and } \\
\text { Kara (2011) }\end{array}$ & $\begin{array}{l}\text { Johansen } \\
\text { multivariate } \\
\text { cointegration } \\
\end{array}$ & Turkey & $\begin{array}{l}1964- \\
2006\end{array}$ & $\begin{array}{l}\text { A unidirectional causality } \\
\text { is tourism receipts and reel } \\
\text { exchange rate to real GDP. }\end{array}$ \\
\hline $\begin{array}{l}\text { Arslanturk } \\
\text { et.al. (2011) }\end{array}$ & $\begin{array}{l}\text { Vector Error } \\
\text { Correction } \\
\text { Model }\end{array}$ & $\begin{array}{l}\text { small } \\
\text { open economy }\end{array}$ & $\begin{array}{l}1993- \\
2006\end{array}$ & $\begin{array}{l}\text { There is no causality } \\
\text { between the series. }\end{array}$ \\
\hline
\end{tabular}




\begin{tabular}{|c|c|c|c|c|}
\hline Authors & Method & Counrty & Period & Findings \\
\hline $\begin{array}{l}\text { Ekanayake \& } \\
\text { Long (2012) }\end{array}$ & FMOLS & $\begin{array}{l}\text { developing } \\
\text { countries }\end{array}$ & $\begin{array}{l}1995- \\
2009\end{array}$ & $\begin{array}{l}\text { Tourism receipts promote } \\
\text { economic growth } \\
\text { in developing countries. }\end{array}$ \\
\hline $\begin{array}{l}\text { Dritsakis } \\
(2012)\end{array}$ & FMOLS & $\begin{array}{l}\text { Mediterranean } \\
\text { countries }\end{array}$ & $\begin{array}{l}1980- \\
2007 .\end{array}$ & $\begin{array}{l}\text { There is significant } \\
\text { cointegration } \\
\text { between tourism } \\
\text { development and GDP in } \\
\text { the selected Mediterranean } \\
\text { countries. }\end{array}$ \\
\hline $\begin{array}{l}\text { Lee } \\
\& \text { Brahmasrene } \\
(2013)\end{array}$ & Panel data & $\begin{array}{l}\text { European } \\
\text { Union } \\
\text { countries }\end{array}$ & $\begin{array}{l}1998- \\
2009\end{array}$ & $\begin{array}{l}\text { A long-run relation } \\
\text { between } \mathrm{FDI}, \mathrm{CO}_{2} \\
\text { emissions, tourism and } \\
\text { economic growth } \\
\end{array}$ \\
\hline $\begin{array}{l}\text { Ivanov \& } \\
\text { Webster (2013) }\end{array}$ & $\begin{array}{l}\text { Pearson } \\
\text { correlations }\end{array}$ & 174 countries & \begin{tabular}{|l|}
$2000-$ \\
2010 \\
\end{tabular} & $\begin{array}{l}\text { Tourism accounts are a } \\
\text { higher share GDP. }\end{array}$ \\
\hline Chou (2013) & $\begin{array}{l}\text { Panel } \\
\text { causality } \\
\text { analysis }\end{array}$ & $\begin{array}{l}10 \text { transition } \\
\text { countries }\end{array}$ & $\begin{array}{l}1988- \\
2011\end{array}$ & $\begin{array}{l}\text { Growth hypothesis is valid } \\
\text { for Cyprus, Latvia and } \\
\text { Slovakia. } \\
\text { Growth hypothesis is not } \\
\text { valid for Czech Republic } \\
\text { and Poland, while a } \\
\text { feedback hypothesis is } \\
\text { valid for Estonia and } \\
\text { Hungary. }\end{array}$ \\
\hline Tugcu (2014) & $\begin{array}{l}\text { Panel } \\
\text { Granger }\end{array}$ & $\begin{array}{l}\text { Mediterranean } \\
\text { Sea }\end{array}$ & $\begin{array}{l}1998- \\
2011\end{array}$ & $\begin{array}{l}\text { The impact of tourism on } \\
\text { growth is more dominant } \\
\text { than in European countries } \\
\text { and Mediterranean } \\
\text { countries. }\end{array}$ \\
\hline $\begin{array}{l}\text { Martin et.al } \\
(2014)\end{array}$ & $\begin{array}{l}\text { GINI, Pigon- } \\
\text { Dalton }\end{array}$ & \begin{tabular}{|l} 
Spain's \\
Andalusia \\
Region
\end{tabular} & $\begin{array}{l}2005- \\
2010\end{array}$ & $\begin{array}{l}\text { Tourism seasonality is } \\
\text { more intense } \\
\text { in the most } \\
\text { environmentally sensitive } \\
\text { destinations. } \\
\end{array}$ \\
\hline $\begin{array}{l}\text { Pérez- } \\
\text { Rodríguez } \\
(2015)\end{array}$ & GARCH & $\begin{array}{l}\text { UK, Spain and } \\
\text { Croatia }\end{array}$ & $\begin{array}{l}1980- \\
2012 \\
(\mathrm{UK}) \\
1995- \\
2013 \\
\text { (Spain) } \\
1997- \\
2013 \\
\text { (Croatia) }\end{array}$ & $\begin{array}{l}\text { There is a significant, } \\
\text { asymmetric and positive } \\
\text { relation between } \\
\text { tourism and GDP for the } \\
\text { countries. It changes over } \\
\text { time for Croatia. }\end{array}$ \\
\hline
\end{tabular}




\begin{tabular}{|c|c|c|c|c|}
\hline Authors & Method & Counrty & Period & Findings \\
\hline $\begin{array}{l}\text { Brida et.al } \\
(2015)\end{array}$ & Nonlinear & MERCOSUR & $\begin{array}{l}1990- \\
2011\end{array}$ & $\begin{array}{l}\text { There is a cointegration } \\
\text { between per capita } \\
\text { GDP and tourism } \\
\text { expenditure for } \\
\text { selected countries. The } \\
\text { nonparametric causality } \\
\text { tests show the causality } \\
\text { from tourism to growth. }\end{array}$ \\
\hline $\begin{array}{l}\text { Antonakakis } \\
\text { et.al (2015) }\end{array}$ & Time-varying & $\begin{array}{l}10 \text { European } \\
\text { countries }\end{array}$ & $\begin{array}{l}1995- \\
2012\end{array}$ & $\begin{array}{l}\text { The relationship between } \\
\text { tourism and economic } \\
\text { growth does not have a } \\
\text { stable trend. } \\
\text { The results of the analysis } \\
\text { indicate economic growth } \\
\text { based on tourism and } \\
\text { tourism supported by } \\
\text { economic growth in } \\
\text { different periods. }\end{array}$ \\
\hline $\begin{array}{l}\text { Shahzad et.al. } \\
(2017)\end{array}$ & $\begin{array}{l}\text { quantile-on- } \\
\text { quantile (QQ) } \\
\text { approach }\end{array}$ & \begin{tabular}{|l|} 
(China, France, \\
Germany, \\
Italy, Mexico, \\
Russia, Spain, \\
Turkey, the \\
United \\
Kingdom, and \\
the United \\
States) \\
\end{tabular} & $\begin{array}{l}1990- \\
2015\end{array}$ & $\begin{array}{l}\text { There is a positive relation } \\
\text { between tourism } \\
\text { development and economic } \\
\text { growth for all countries, }\end{array}$ \\
\hline $\begin{array}{l}\text { Yalçinkaya } \\
\text { et.al (2018) }\end{array}$ & $\begin{array}{l}\text { panel data } \\
\text { analysis }\end{array}$ & WTR- 20 & $\begin{array}{l}1996- \\
2016\end{array}$ & $\begin{array}{l}\text { The international } \\
\text { tourism revenues have a } \\
\text { positive effect } \\
\text { on economic growth for } \\
\text { WTR-20 }\end{array}$ \\
\hline $\begin{array}{l}\text { Wu and } \mathrm{Wu} \\
(2018)\end{array}$ & $\begin{array}{l}\text { Panel } \\
\text { Causality } \\
\text { Analysis } \\
\end{array}$ & $\begin{array}{l}\text { China's } 31 \\
\text { major regions }\end{array}$ & $\begin{array}{l}1995- \\
2015\end{array}$ & $\begin{array}{l}\text { The growth hypothesis is } \\
\text { valid in the regions. }\end{array}$ \\
\hline $\begin{array}{l}\text { Hatemi-J et.al. } \\
\text { (2018) }\end{array}$ & $\begin{array}{l}\text { asymmetric } \\
\text { panel } \\
\text { causality test }\end{array}$ & G-7 countries & $\begin{array}{l}1995- \\
2014 .\end{array}$ & $\begin{array}{l}\text { Tourism-Led Growth } \\
\text { Hypothesis (TLGH) valid } \\
\text { for France, Germany and } \\
\text { the US. }\end{array}$ \\
\hline
\end{tabular}


Ö. B. SOYLU: Panel granger causality analysis of relationships between tourism and economic growth in the top... EKONOMSKI PREGLED, 71 (4) 407-430 (2020)

\begin{tabular}{|l|l|l|l|l|}
\hline Authors & Method & Counrty & Period & Findings \\
\hline $\begin{array}{l}\text { Eyuboğlu S. } \\
\text { \&Eyuboğlu K. } \\
(2020)\end{array}$ & $\begin{array}{l}\text { The Konya } \\
\text { (2006) panel } \\
\text { causality test }\end{array}$ & $\begin{array}{l}\text { 9 emerging } \\
\text { countries. }\end{array}$ & $\begin{array}{l}1995- \\
2016\end{array}$ & $\begin{array}{l}\text { The neutrality hypothesis } \\
\text { is valid in emerging } \\
\text { countries. }\end{array}$ \\
\hline $\begin{array}{l}\text { Akadiri et.al } \\
(2020)\end{array}$ & $\begin{array}{l}\text { The Konya } \\
\text { (2006) panel } \\
\text { causality test }\end{array}$ & $\begin{array}{l}16 \text { tourism } \\
\text { island states }\end{array}$ & $\begin{array}{l}1995- \\
2014\end{array}$ & $\begin{array}{l}\text { The demand-flowing and } \\
\text { supply-leading hypotheses } \\
\text { are supported. }\end{array}$ \\
\hline
\end{tabular}

Source: Authors`collections

The findings of the studies differ according to the macroeconomic indicators that interact with tourism, groups of countries and period. However, studies examining the relationship between tourism activities and economic growth have similar findings. Most of the studies have pointed out the positive impact of tourism activities on economic growth (Hatemi-J et.al. (2018), Yalçinkaya et.al (2018), Shahzad et.al. (2017), Brida et.al (2015), Tugcu ( 2014), Ekanayake \& Long (2012), Mahmoudinia et. al (2011), Nissan et.al. (2011), Lee \& Chang (2008)).

The purpose of this study is to examine the causality relationship between tourism expenditures, tourism receipts and number of international arrivals, which are among the important components of tourism activities, and economic growth with the help of cointegration and causality analysis.

\section{Data and Methodogy}

The data set consist of annual real GDP (in current US\$), annual international number of arrivals, annual international tourism receipts (in current US\$), annual international tourism expenditures (in Current US\$) over 1995-2017. The total number of international arrivals, international tourism receipts and international tourism expenditures are key variables to measure the size of tourism (Balaguer and Cantavella-Jorda, 2002, Kim et al., 2006; Chiou-Wei, 2009; Shahzad et.al, 2017). The number of arrivals of international tourists, international tourism receipts and international tourism expenditures data were obtained from World Bank's World Development Indicators.

The panel consists of a combination of time series and horizontal section data. The panel is derived from a horizontal cross-sectional datum that repeats the samples over time; but here the same economic unit is followed during the sampling period. The logarithms of the data were taken. 


\subsection{Cross-Sectional Dependence ve Slope Homogeneity of Coefficients}

The countries under consideration stand out in terms of being the countries with the most popular tourism populations and that tourism activity have an important place within this country group within the economic activity. Unlike the causality tests conducted in the studies in the literature, considering the crosssectional dependence also distinguishes it from other studies. It is thought that the results obtained in this regard will contribute to the literature. With the help of panel causality analysis, it is aimed to decide on the capacity of developments in tourism activities to affect economic growth. Thus, this study aims to contribute to the literature examining the effect of tourism on economic growth in popular tourism destinations.

Panel unit root tests are examined under two generations according to whether there is a correlation between units. It is important to test the existence of a correlation between units before applying a unit root test in this respect. Several tests have been developed to test the inter-unit correlation. The most appropriate test for asymptotic properties data set should be preferred by testing the correlation between units.

It is typically, assumed that disturbances in panel data models are cross-sectional independent (Peseran 2004). The countries of the panel, the units of horizontal sections, are independent; based on the assumption that all horizontal cross-sectional units are affected at the same level and that no other countries are affected by a macroeconomic shock in any of the countriesIt is necessary to test whether there is a cross-section dependency between the series before starting the analysis since the results obtained in the analyses performed without considering the cross-section dependence will be deviant and inconsistent. Three tests are generally used to test the cross-sectional dependence in panel data analysis. Breusch-Pagan (1980) argues that the cross sectional dependence is valid when $\mathrm{N}$ is constant and $\mathrm{T}$ goes to infinity $(\mathrm{T} \rightarrow \infty)$, in other words; $\mathrm{T}>\mathrm{N}$. Breusch-Pagan (1980) cross-sectional dependence test was developed under the "No cross-sectional dependency" null hypothesis. It is calculated by the following equation.

$$
C D_{B P}=T \sum_{t=1}^{N-1} \sum_{j=i+1}^{N} \dot{\rho}_{t, j}^{2}
$$

The second cross-sectional dependence test is the CDLM test developed by Pesaran (2004). This test is valid if $\mathrm{T}$ and $\mathrm{N}$ are large $(\mathrm{N} \rightarrow \infty$ and $\mathrm{T} \rightarrow \infty)$ ). The test has standard normal distribution under the null hypothesis "no cross-sectional dependency" and it is calculated as follows: 


$$
C D_{L M 1}=\sqrt{1 / N(N-1)} \sum_{t=1}^{N-1} \sum_{j=i+1}^{N}\left(T \dot{\rho}_{t, j}^{2}-1\right)
$$

The CDLM test developed by Pesaran (2004), one of the cross-sectional dependence tests, has a standard normal distribution under the null hypothesis "No cross-sectional dependency". This test is valid when $\mathrm{T}$ is constant and $\mathrm{N}$ is infinity $(\mathrm{N} \rightarrow \infty)$. In other words, the test is valid when $\mathrm{N}>\mathrm{T}$ and calculated as follows:

$$
C D_{L M}=\sqrt{2 T / N(N-1)}\left(\sum_{t=1}^{N-1} \sum_{j=i+1}^{N} \dot{\rho}_{i, j}\right.
$$

Another cross-sectional dependence test is LMadj (bias-adjusted) which was performed by Pesaran et al. (2008). $\mu$ Tij and $v T i j$ are the mean and variance of ( T - k) Q $Q^{\wedge}$ ij2 proposed by Pesaran et al. (2008). LMadj exhibits normal asymptotic standard distribution while $\mathrm{T} \rightarrow \infty$ and $\mathrm{N} \rightarrow \infty$ altında under the null hypothesis that there is no horizontal cross-section dependence. Breusch and Pagan (1980) LM test and Pesaran et al. (2008) (bias-adjusted) LM test is applied since T is larger $\mathrm{N}(\mathrm{T}>\mathrm{N})$.

$$
L M_{a d j}=\sqrt{2 / N(N-1)}\left(\sum_{i=1}^{N-1} \sum_{j=i+1}^{N} T \dot{\rho}_{i, j} \frac{(T-k) \dot{\rho}_{i j}^{2}-\mu_{T i j}}{\sqrt{\dot{u}_{T i j}^{2}}}\right.
$$

The Cross-Section Dependence Test Results is presented in Table 2. All variables have inter-unit correlation according to the results. Therefore, the second generation unit root tests should be preferred. The second-generation unit root tests include homogeneous and heterogeneous unit root tests. Swammy's S (1970) test should be performed to find out which test group is preferred. 
Table 2.

\section{CROSS-SECTION DEPENDENCE TEST RESULTS}

\begin{tabular}{|c|c|c|}
\hline Variable & \multicolumn{2}{|c|}{ GDP } \\
\hline Test & Statistic & p-value \\
\hline LM & 186.5 & 0.0 \\
\hline LM adj* & 48.5 & 0.0 \\
\hline Variable & Arrivals & 0.0 \\
\hline LM & 54.63 & 0.0 \\
\hline LM adj* & 7.618 & 0.0 \\
\hline Variable & Receipts & 0.0 \\
\hline LM & 93.77 & \\
\hline LM adj* & 19.82 & 0.0 \\
\hline Variable & Expenditures & 0.0 \\
\hline LM & 48.77 & \\
\hline LM adj* & 5.685 & \\
\hline
\end{tabular}

Source: Authors`calculations

Table 2 indicates the horizontal cross-section dependence in the series by rejecting the $\mathrm{H} 0$ hypothesis since the probability values for the GDP, arrivals, receipts and expenditures variables are less than 0.05 in the LM and LMadj tests. Horizontal cross-section dependency between series is an important indicator for policymakers as it states that the shock that occurs in any country participating in the analysis will affect other countries as well.

The second-generation unit root tests include homogeneous and heterogeneous unit root tests. Swammy's S (1970) test should be performed to find out which test group is preferred.

$$
\dot{S}=\sum_{i=1}^{N}\left(\beta_{i}-\beta_{W F E}\right) \frac{\dot{X}_{i} M \quad X_{\dot{1}}}{\sigma_{i}^{2}}\left(\beta_{i}-\beta_{W F E}\right)
$$

More recently, Pesaran and Yamagata (2008) suggest a dispersion type test based on Swamy (1970) type test. They standardize the Swamy type test so that the test can be applied when both $\mathrm{n}$ and $\mathrm{T}$ are large. The Swamy S Test Results is presented in Table 3. 
Ö. B. SOYLU: Panel granger causality analysis of relationships between tourism and economic growth in the top... EKONOMSKI PREGLED, 71 (4) 407-430 (2020)

Table 3.

\section{THE SWAMY S TEST RESULTS}

\begin{tabular}{|c|c|c|}
\hline Variable & \multicolumn{2}{|c|}{ GDP } \\
\hline Test & Statistic & p-value \\
\hline Swammy's S & 31.79 & 0.0615 \\
\hline Variable & Arrivals & \\
\hline Swammy's S & 24.84 & 0.2542 \\
\hline Variable & Receipts & \\
\hline Swammy's S & 24.07 & 0.2898 \\
\hline Variable & Expenditures & \\
\hline Swammy's S & 25.98 & 0.2073 \\
\hline
\end{tabular}

Source: Authors`calculations

As the probability values of the homogeneity tests performed to determine whether the slope coefficients differ between horizontal cross-sectional units, the result is that the constant and slope coefficients in the model are homogeneous. The autoregressive parameter of all variables is homogeneous according to test results. Therefore, it would be more appropriate to prefer the homogeneous group of second-generation unit root tests.

\subsection{Unit Root}

The graphical analysis is important to determine the specification of the model before applying unit root tests. Therefore, graphs should be examined before proceeding to unit root tests. The graphs are shown for all four variables in the following figures. According to the graphs, it is seen that the variables generally contain constant but not trend. Breitung (2000) unit root test with asymptotic characteristics and Hadri (2000) stationarity test (mean-adjusted) are applied to the variables according to this specification. The graphs are presented in Appendix 1.

Breitung (2000) suggested that the corrected $t$ statistic he used to test the unit root was biased and that this statistic, especially when used in individual trend models, resulted in the loss of power, suggesting a new t statistic (Breitungen, 2000: 24).

$$
y_{i t}=\alpha_{i t}+\sum_{k=1}^{p+1} \beta_{i k} X_{i, t-k}+\varepsilon_{i t}
$$


Hadri (2000) tests the alternative hypothesis that defends the existence of a unit root against the null hypothesis, which states that there is no unit root in any of the series in the panel. The Hadri unit root test is a test based on the error terms obtained as a result of the series based on Lagrange Multiplier (LM) test with a constant or constant and least-squares method on trend. The Hadri and Breitung test results are presented in table 4. Table 4 represents unit root results of gdp, table 4a represents unit root results of arrivals, table $4 \mathrm{~b}$ represents unit root results of receipts and table $4 \mathrm{c}$ represents unit root results of expenditures.

Table 4.

UNIT ROOT TEST RESULTS (GDP)

\begin{tabular}{|c|c|c|}
\hline Variable & \multicolumn{2}{|c|}{ GDP } \\
\hline Test & Statistic & p-value \\
\hline Breitung & 2.0017 & 0.9773 \\
\hline Hadri & 32.6716 & 0.0000 \\
\hline Variable & \multicolumn{2}{|c|}{ dGDP } \\
\hline Test & Statistic & p-value \\
\hline Breitung & -4.7548 & 0.0000 \\
\hline Hadri & -0.2136 & 0.5846 \\
\hline
\end{tabular}

Table $4 a$.

UNIT ROOT TEST RESULTS (ARRIVALS)

\begin{tabular}{|l|c|c|}
\hline Variable & \multicolumn{2}{|c|}{ Arrivals } \\
\hline Test & Statistic & p-value \\
\hline Breitung & 1.7968 & 0.9638 \\
\hline Hadri & 29.8879 & 0.0000 \\
\hline Variable & Statistic & dArrivals \\
\hline Test & -2.1936 & 0.0141 \\
\hline Breitung & 1.4170 & 0.0782 \\
\hline Hadri & & \\
\hline
\end{tabular}


Ö. B. SOYLU: Panel granger causality analysis of relationships between tourism and economic growth in the top...

Table $4 b$.

\section{UNIT ROOT TEST RESULTS (RECEIPTS)}

\begin{tabular}{|c|c|c|}
\hline Variable & \multicolumn{2}{|c|}{ Receipts } \\
\hline Test & Statistic & $\mathrm{p}$-value \\
\hline Breitung & 1.1418 & 0.8732 \\
\hline Hadri & 23.6359 & 0.0000 \\
\hline Variable & dReceipts \\
\hline Test & Statistic & p-value \\
\hline Breitung & -2.6520 & 0.0040 \\
\hline Hadri & 0.0235 & 0.4906 \\
\hline
\end{tabular}

Table $4 c$.

\section{UNIT ROOT TEST RESULTS (EXPENDITURES)}

\begin{tabular}{|c|c|c|}
\hline Variable & \multicolumn{2}{|c|}{ Expenditures } \\
\hline Test & Statistic & $\mathrm{p}$-value \\
\hline Breitung & 3.1154 & 0.9991 \\
\hline Hadri & 30.6124 & 0.0000 \\
\hline Variable & \multicolumn{2}{|c|}{ dExpenditures } \\
\hline Test & Statistic & p-value \\
\hline Breitung & -4.6800 & 0.0000 \\
\hline Hadri & 0.2395 & 0.4054 \\
\hline
\end{tabular}

Source: Authors`calculations

The Hadri and Breitung test: The Breitung test results show that the probability values of the GDP, arrivals, receipts and expenditures indicators are greater than 0.05 , they are not stationary at the level, and they are stationary when their first difference is taken. According to the results of the Hadri unit root test, the Ho hypothesis probability values, which are established as the units in the panel data set are stationary, are significant at the level of $0.05(\mathrm{p}<0.05)$. In other words, the null hypothesis is rejected. It is shown that the series is stationary from the first level by taking the first differences. 
Table 5.

\section{INTER-UNIT CORRELATION TEST RESULTS}

\begin{tabular}{|c|c|c|}
\hline Test & Statistic & p-value \\
\hline LM & 37.23 & 0.1139 \\
\hline LM adj* & 1.93 & 0.0536 \\
\hline
\end{tabular}

Source: Authors`calculations

It is seen that all variables are stationary in the first differences according to unit root test results. The cointegration test can be applied to the variables since all variables are stationary in their first differences. Cointegration tests are divided into first and second generation cointegration tests according to the existence of inter-unit correlation. Inter-unit correlation test results are in the following table 5.

\subsection{Panel Cointegration Test}

The cointegration test examines the long-run equilibrium relationship between the series. It would be more accurate to use first-generation cointegration tests according to the test results. One of the first generation cointegration tests, the Pedroni cointegration test contains homogeneous and heterogeneous statistics. Swammy's S test was used to determine which one would prefer.

Table 6.

\section{SWAMMY'S S TEST RESULT FOR COINTEGRATION}

\begin{tabular}{|c|c|c|}
\hline Test & Statistic & p-value \\
\hline Swammy's S & 4135.36 & 0.0000 \\
\hline
\end{tabular}

Source: Authors`calculations 
According to the results of the test, it is necessary to use the heterogeneous test statistics of Pedroni cointegration test. The table 7 represents the results of cointegration. The Pedroni cointegration test can be explained by following equation :

$$
y_{i t=} \alpha_{i}+\delta_{i} t+\beta_{1 i} X_{1 i t}+\beta_{2 i} X_{2 i t}+\ldots
$$

Table 7.

\section{PEDRONI PANEL COINTEGRATION TEST RESULTS}

\begin{tabular}{|c|c|}
\hline Test & Group Statistic \\
\hline Rho & 1.034 \\
\hline $\mathrm{t}$ & -1.499 \\
\hline ADF & 1.214 \\
\hline
\end{tabular}

Source: Authors`calculations

The cointegration relationship between variables cannot be mentioned since all test statistics are less than 1.96. If the series is stationary at the first level after the unit-roots, cointegration analysis is carried out to investigate whether there is a long-term relationship between the series. Pedroni panel cointegration takes into account the heterogeneity in the cointegration vector. Thus, while allowing dynamic and constant effects to be different between the horizontal sections of the panel, it also allows differentiation of the cointegrated vector between sections under the alternative hypothesis (Egeli and Egeli, 2007). The existence of cointegration among the indicators is accepted for the countries of popular destinations in the long term.

\subsection{Panel Granger Test}

Panel causality tests are divided into two groups according to their homogeneity or heterogeneity. For Swammy's $S$ test to be applied to the appropriate VAR specification, the lag length of the VAR model must be determined. The instrumental variables are valid for all delays according to Hansen's J test. The appro- 
priate delay was found 1 according to all information criteria. Table 8 represents the the lag length determination.

Table 8.

THE LAG LENGTH DETERMINATION

\begin{tabular}{|c|c|c|c|c|c|c|}
\hline lag & CD & J & J pvalue & MBIC & MAIC & MQIC \\
\hline 1 & 0.783853 & 64.81275 & 0.448108 & -227.306 & -63.1873 & -129.527 \\
\hline 2 & -1.07744 & 38.48898 & 0.835007 & -180.6 & -57.511 & -107.266 \\
\hline 3 & -3.13226 & 27.5042 & 0.693648 & -118.555 & -36.4958 & -69.6654 \\
\hline 4 & -86.2684 & 4.076532 & 0.998765 & -68.953 & -27.9235 & -44.5083 \\
\hline
\end{tabular}

Swammy's $\mathrm{S}$ test result based on 1-delay VAR model specification is expressed below.

Table 9.

SWAMMY'S S TEST RESULT FOR PANEL GRANGER CASUALITY

\begin{tabular}{|c|c|c|}
\hline Test & Statistic & p-value \\
\hline Swammy's S & 42.60 & 0.1766 \\
\hline
\end{tabular}

According to the test result, a homogeneous Panel Granger causality test should be applied. The results of granger test is presented folloving table. According to panel causality results, there is a two-way causality relationship between GDP and expenditures and receipts for selected countries. 
Ö. B. SOYLU: Panel granger causality analysis of relationships between tourism and economic growth in the top... EKONOMSKI PREGLED, 71 (4) 407-430 (2020)

Table 10.

PANEL GRANGER TEST RESULTS

\begin{tabular}{|c|c|c|c|c|}
\hline Equation & Excluded & Test Statistic & DF & Prob \\
\hline \multirow{4}{*}{ GDP } & Arrivals & 0.389 & 1 & 0.533 \\
\hline & Expenditures & 1.217 & 1 & 0.0005 \\
\hline & Receipts & 6.6050 & 1 & 0.0000 \\
\hline & All & 3.089 & 3 & 0.378 \\
\hline Equation & Excluded & Test Statistic & DF & Prob \\
\hline \multirow{4}{*}{ Arrivals } & GDP & 0.009 & 1 & 0.926 \\
\hline & Expenditures & 0.347 & 1 & 0.556 \\
\hline & Receipts & 0.029 & 1 & 0.866 \\
\hline & All & 0.447 & 3 & 0.93 \\
\hline Equation & Excluded & Test Statistic & DF & Prob \\
\hline \multirow{4}{*}{ Expenditures } & GDP & 3.929 & 1 & 0.047 \\
\hline & Arrivals & 0.227 & 1 & 0.634 \\
\hline & Receipts & 1.157 & 1 & 0.282 \\
\hline & All & 4.251 & 3 & 0.236 \\
\hline Equation & Excluded & Test Statistic & DF & Prob \\
\hline \multirow{4}{*}{ Receipts } & GDP & 4.738 & 1 & 0.03 \\
\hline & Arrivals & 3.089 & 1 & 0.079 \\
\hline & Expenditures & 1.691 & 1 & 0.193 \\
\hline & All & 16.407 & 3 & 0.001 \\
\hline
\end{tabular}

The results of the casuality tests reflect the dynamics of the tourism for selected country groups. The results indicate that economic growth and tourism expenditures and receipts are in bi-directional interaction. The tourism expenditures and receips are one of the driving force of the economic growth. The economic growth and development are also of great importance for tourism expenditures and receipts. 


\section{Conclusions and Some Policy Implications}

This study investigates the empirical validity of cointegration and granger casuality for the top eight tourist destinations worldwide over the period 1995 -2017 using the Panel Granger Causality Tests. The results are important in terms of the development and the causation of the tourism. Policy makers should consider the fact that expenditures and receipts contribute to economic growth. At the same time, the bidirectional causality is an important result for the policy makers' tourism policies. The results of this study, which is a peculiar study in terms of the countries addressed in the period analyzed, are similar to those that indicate that tourism activities have a positive effect on economic growth (Hatemi-J et.al. (2018), Yalçinkaya et.al (2018), Shahzad et.al. (2017), Brida et.al (2015), Tugcu ( 2014), Ekanayake \& Long (2012), Mahmoudinia et. al (2011), Nissan et.al. (2011), Lee \& Chang (2008)). On the other hand, unlike studies examining different numbers of popular destinations (Shahzad et.al. (2017) , a unidirectional causality relationship has been identified.

The tourism is an important sector which is developing and expanding day by day with all its components. The contribution of the tourism to the economy and structure of the country in economic, social and cultural terms is a fact. The arrivals of tourists, expenditure levels of tourists and tourism receipts are important indicators for the national economies. The positive effects of these indicators on the balance of payments, being a source of foreign exchange, employment creation, triggering investment in infrastructure and superstructure and creating a revitalizing effect in other sectors, have an important place in the region and country economy with their socio-cultural reflections. (Bozgeyik and Yoloğlu, 2015).

The increase in travel expenditures and transportation opportunities in the subject matter of the study encourages the economies of the country to take a share from the tourism markets and brings competition in tourism. To achieve maximum efficiency from their tourism activities, they focus on demand-oriented factors of the country's economies, primarily advertising, public relations, sales development, brand, image, product variety and expenditure per tourist. They should also implement actions that will trigger growth by increasing tourism revenues and spending per tourist, focusing on quantitative and qualitative factors of the country's economies. Both demand-side factors and quantitative and qualitative factors are even more important for the post-COVID-19 period. Therefore, focusing on these factors, focusing on tourism markets with high spending potential, marketing and promotion organizations, integration of economic, social, political and psychological factors that will appeal to the high-income tourist profile is important for the future of tourism, especially in popular destinations where growth will shrink globally. 
Ö. B. SOYLU: Panel granger causality analysis of relationships between tourism and economic growth in the top... EKONOMSKI PREGLED, 71 (4) 407-430 (2020)

\section{References:}

1. Akadiri, S. S., Lasisi, T. T., Uzuner, G., \& Akadiri, A. C. (2020). Examining the causal impacts of tourism, globalization, economic growth and carbon emissions in tourism island territories: bootstrap panel Granger causality analysis. Current Issues in Tourism, 23(4), 470-484.

2. Antonakakis, N., Dragouni, M., \& Filis, G. (2015). How strong is the linkage between tourism and economic growth in Europe?. Economic Modelling, 44, 142-155.

3. Archer, B. (1995). Importance of tourism for the economy of Bermuda. Annals of tourism research, 22(4), 918-930.

4. Arslanturk, Y., Balcilar, M., \& Ozdemir, Z. A. (2011). Time-varying linkages between tourism receipts and economic growth in a small open economy. Economic Modelling, 28(1-2), 664-671.

5. Balaguer, J., \& Cantavella-Jorda, M. (2002). Tourism as a long-run economic growth factor: the Spanish case. Applied economics, 34(7), 877-884.

6. Belisle, F. J., \& Hoy, D. R. (1980). The perceived impact of tourism by residents a case study in Santa Marta, Colombia. Annals of tourism research, 7(1), 83-101.

7. Belloumi, M. (2010). The relationship between tourism receipts, real effective exchange rate and economic growth in Tunisia. International Journal of Tourism Research, 12(5), 550-560.

8. Bhagwati, J., \& Srinivasan, T. N. (1979). Trade policy and development. International economic policy: Theory and evidence, 1, 1-35.

9. Brida, J. G., Cortes-Jimenez, I., \& Pulina, M. (2016). Has the tourism-led growth hypothesis been validated? A literature review. Current Issues in Tourism, 19(5), 394-430.

10. Brida, J. G., Lanzilotta, B., Pereyra, J. S., \& Pizzolon, F. (2015). A nonlinear approach to the tourism-led growth hypothesis: The case of the MERCOSUR. Current Issues in Tourism, 18(7), 647-666.

11. Chen, C. F., \& Chiou-Wei, S. Z. (2009). Tourism expansion, tourism uncertainty and economic growth: New evidence from Taiwan and Korea. Tourism Management, 30(6), 812-818.

12. Chou, M. C. (2013). Does tourism development promote economic growth in transition countries? A panel data analysis. Economic Modelling, 33, 226-232.

13. Cortes-Jimenez, I., \& Pulina, M. (2010). Inbound tourism and long-run economic growth. Current Issues in Tourism, 13(1), 61-74. 
14. Çetintaş, H., \& Bektaş, Ç. (2008). Türkiye>de turizm ve ekonomik büyüme arasındaki kısa ve uzun dönemli ilişkiler. Anatolia: Turizm Araştırmaları Dergisi, 19(1), 37-44.

15. da Costa Ribeiro, E., \& Wang, B. (2020). Tourism Led Growth Hypothesis: Has the Tourism industry an impact on The Economic Growth of Sao Tome and Principe?. International Journal of Economics and Financial Issues, 10(1), 180-185.

16. Davis, D., Allen, J., \& Cosenza, R. M. (1988). Segmenting local residents by their attitudes, interests, and opinions toward tourism. Journal of travel research, 27(2), 2-8.

17. Dritsakis, N. (2004), 'Tourism as a long-run economic growth factor: an empirical investigation for Greece using a causality analysis', Tourism Economics, Vol 10, pp 305-316.

18. Dritsakis, N. (2012). Tourism development and economic growth in seven Mediterranean countries: A panel data approach. Tourism Economics, 18(4), 801-816.

19. Durbarry, R. (2004). Tourism and economic growth: the case of Mauritius. Tourism Economics, 10(4), 389-401.

20. Egeli, H. A., \& Egeli, P. (2007). İhracat-milli gelir ilişkisi: asya ülkeleri üzerine panel veri analizi. Uluslararası Asya Ve Kuzey Afrika Çalısmaları Kongresi, Ankara/Türkiye.

21. Ekanayake, E. M., \& Long, A. E. (2012). Tourism development and economic growth in developing countries. The International Journal of Business and Finance Research, 6(1), 61-63.

22. Eyuboglu, S., \& Eyuboglu, K. (2020). Tourism development and economic growth: an asymmetric panel causality test. Current Issues in Tourism, 23(6), 659-665.

23. Hadri, K. (2000). Testing for stationarity in heterogeneous panel data. The Econometrics Journal, 3(2), 148-161.

24. Hatemi-J, A., Gupta, R., Kasongo, A., Mboweni, T., \& Netshitenzhe, N. (2018). Does tourism cause growth asymmetrically in a panel of G-7 countries? A short note. Empirica, 45(1), 49-57.

25. Helpman, E and Krugman, P. (1985) Market Structure and Foreign trade, MIT Press, Cambridge

26. Husein, J., \& Kara, S. M. (2011). Research note: Re-examining the tourismled growth hypothesis for Turkey. Tourism Economics, 17(4), 917-924.

27. Im, K. S., Pesaran, M. H., \& Shin, Y. (2003). Testing for unit roots in heterogeneous panels. Journal of Econometrics, 115(1), 53-74

28. Ivanov, S. H., \& Webster, C. (2013). Tourism's contribution to economic growth: a global analysis for the first decade of the millennium. Tourism Economics, 19(3), 477-508. 
29. Kim, H. J., Chen, M. H., \& Jang, S. C. (2006). Tourism expansion and economic development: The case of Taiwan. Tourism Management, 27, 925-933.

30. Lee, C. C., \& Chang, C. P. (2008). Tourism development and economic growth: A closer look at panels. Tourism management, 29(1), 180-192.

31. Lee, C. G. (2012). Tourism, trade, and income: Evidence from Singapore. Anatolia, 23(3), 348-358.

32. Lee, J. W., \& Brahmasrene, T. (2013). Investigating the influence of tourism on economic growth and carbon emissions: Evidence from panel analysis of the European Union. Tourism management, 38, 69-76.

33. Levin, A., Lin, C. F., \& Chu, C. S. J. (2002). Unit root tests in panel data: asymptotic and finite-sample properties. Journal of Econometrics, 108(1), 1-24

34. Mahmoudinia, D., Salimi Soderjani, E., \& Pourshahabi, F. (2011). Economic growth, tourism receipts and exchange rate in MENA zone: Using panel causality technique. Iranian Economic Review, 15(29), 129-146.

35. Marin, D. (1992). Is the export-led growth hypothesis valid for industrialized countries?. Review of Economics \& Statistics, (4), 678-688.

36. Martín, J. M. M., Aguilera, J. D. D. J., \& Moreno, V. M. (2014). Impacts of seasonality on environmental sustainability in the tourism sector based on destination type: An application to Spain's Andalusia region. Tourism Economics, 20(1), 123-142.

37. Nissan, E., Galindo, M. A., \& Méndez, M. T. (2011). Relationship between tourism and economic growth. The Service Industries Journal, 31(10), 15671572

38. Oh, C. O. (2005). The contribution of tourism development to economic growth in the Korean economy. Tourism management, 26(1), 39-44.

39. Pablo-Romero, M. D. P., \& Molina, J. A. (2013). Tourism and economic growth: A review of empirical literature. Tourism Management Perspectives, 8, 28-41.

40. Payne, J. E., \& Mervar, A. (2010). Research note: The tourism-growth nexus in Croatia. Tourism Economics, 16(4), 1089-1094.

41. Pérez-Rodríguez, J. V., Ledesma-Rodríguez, F., \& Santana-Gallego, M. (2015). Testing dependence between GDP and tourism's growth rates. Tourism Management, 48, 268-282.

42. Pesaran, M. H. (2004). General diagnostic tests for cross section dependence in panels.,

43. Sequeira, T. N., \& Maçãs Nunes, P. (2008). Does tourism influence economic growth? A dynamic panel data approach. Applied Economics, 40(18), 24312441.

44. Shahbaz, M., Kumar, R. R., Ivanov, S., \& Loganathan, N. (2017). The nexus between tourism demand and output per capita with the relative importance 
of trade openness and financial development: A study of Malaysia. Tourism Economics, 23(1), 168-186.

45. Shahzad, S. J. H., Shahbaz, M., Ferrer, R., \& Kumar, R. R. (2017). Tourismled growth hypothesis in the top ten tourist destinations: New evidence using the quantile-on-quantile approach. Tourism Management, 60, 223-232.

46. Song, H., Li, G., Witt, S. F., \& Fei, B. (2010). Tourism demand modelling and forecasting: How should demand be measured? Tourism Economics, 16, 63-81.

47. Swamy, P. A. (1970). Efficient inference in a random coefficient regression model. Econometrica: Journal of the Econometric Society, 311-323.

48. Tugcu, C. T. (2014). Tourism and economic growth nexus revisited: A panel causality analysis for the case of the Mediterranean Region. Tourism Management, 42, 207-212.

49. Wu, T. P., \& Wu, H. C. (2018). The influence of international tourism receipts on economic development: evidence from China's 31 major regions. Journal of Travel Research, 57(7), 871-882.

50. Yalçinkaya, Ö., Daştan, M., \& Karabulut, K. (2018). The Effects of International Tourism Receipts on Economic Growth: Evidence from the First 20 Highest Income Earning Countries from Tourism in the World (19962016). Montenegrin Journal of Economics, 14(3), 55-71.

\section{PANEL GRANGEROVA UZROČNA ANALIZA ODNOSA TURIZMA I EKONOMSKOG RASTA U OSAM NAJBOLJIH TURISTIČKIH ODREDIŠTA}

Sažetak

Turizam ima ekonomske, socijalne i političke učinke i doprinosi ekonomskom razvoju mnogih zemalja. Razina interakcije nacionalnih gospodarstava povećava se sturizmom kroz globalizaciju. Ovo istraživanje ima za cilj da ispita uzročno-posljedične veze između komponenti turizma i gospodarskog rasta. Odnos uzročno-posljedičnih komponenti turizma i ekonomskog rasta primjenom panel analize uzročnosti. Rezultati pokazuju dvosmjernu povezanost između rasta $i$ turističkih rashoda i prihoda od turizma. Turistički izdaci, turistički primici i broj međunarodnih dolazaka parametri su turizma. Kao pokazatelj rasta koristi se stvarni omjer bruto domaćeg proizvoda. Analizirano je najboljih osam turističkih destinacija; Španjolska, Italija, Rusija, Turska, Francuska, Kina, SAD, Velika Britanija. U ovom kontekstu; provedena je panel panela za najboljih osam turističkih zemalja u razdoblju od 1995. do 2017. godine. Dolasci turista, razine rashoda turista i primanja od turizma važni su pokazatelji nacionalnih gospodarstava. Pozitivni učinci ovih pokazatelja na platnu bilancu, kao izvor deviza, stvaranje novih radnih mjesta, pokretanje ulaganja u infrastrukturu i nadgradnju i stvaranje revitalizirajućih učinaka u ostalim sektorima, imaju važno mjesto u regiji i ekonomiji zemlje sa svojim socijalnim -kulturna razmišljanja.

Ključne riječi: Ekonomski rast, turistički rashodi, turistički primici, broj međunarodnih dolazaka, Grangerova uzročnost 